\title{
An Allometric Growth Estimation of Grapes (Vitis vinifera L) from High Mountainous Region of Gilgit-Baltistan, Pakistan
}

\author{
Shaheen Kausar, Sidra Asad, Chandni Kiran, Tika Khan* \\ Department of Biological Sciences Karakorum International University, Gilgit, Gilgit-Baltistan, Pakistan \\ Email address: \\ tika.khan@kiu.edu.pk (T. Khan) \\ ${ }^{*}$ Corresponding author \\ To cite this article: \\ Shaheen Kausar, Sidra Asad, Chandni Kiran, Tika Khan. An Allometric Growth Estimation of Grapes (Vitis vinifera L) from High \\ Mountainous Region of Gilgit-Baltistan, Pakistan. American Journal of Biological and Environmental Statistics. \\ Vol. 3, No. 4, 2017 pp. 81-84. doi: 10.11648/j.ajbes.20170304.15
}

Received: June 7, 2017; Accepted: July 7, 2017; Published: January 14, 2018

\begin{abstract}
Grapes (Vitis vinifera), besides their medicinal and health importance, plays an important role in livelihood of poor populations living across mighty mountain ranges of Himalaya, Karakoram and Hindukush. Allometric study is necessary to understand quantitative correlations of tree growth. Hundred plant samples $(\mathrm{n}=100)$ from ten populations $(\mathrm{N}=10)$ were studied at an elevation of 1854 meters asl. Ten $(\mathrm{N}=10)$ different population studied revealed that mean leaf length is $10.9 \mathrm{~cm}$ (max. 13.4, $\min .9 .1 \mathrm{~cm})$ followed by mean leaf width $8.4 \mathrm{~cm}(\max .9 .3$, min. $7.1 \mathrm{~cm})$. total mean leaf area was $92.2 \mathrm{~cm}^{2}(\max$. 122.6, min. $70.9 \mathrm{~cm}^{2}$ ). Mean stem length recorded was 26.8 feet (max. 35, min. 16 feet) followed by mean stem width $8.44 \mathrm{~cm}$ (max. 12.8, $\min .3 .1 \mathrm{~cm}$ ). one thousand seeds were measured and mean seed weight recorded was $0.043 \mathrm{mg}$ (max. 0.047 , min. 0.039). similarly mean weight of hundred $(n=100)$ seeds recorded was $4.29 \mathrm{~g}$. research was summarized with the fact that stem length grows $98.97 \%$ faster than its width increase. Which means $1 \mathrm{~cm}$ with increase corresponds almost $100 \mathrm{~cm}$ increase in length. Similarly, leaf length increase is $23 \%$ higher to its growth in width. Ignorance towards a rich varietal base is on erosion.
\end{abstract}

Keywords: Livelihood, Climate Change, Medicinal, Growth Estimation, Karakoram, Himalaya, Hindukush

\section{Introduction}

Vitis vinifera L. (wine grape) belongs to family Vitaceae. Genus Vitis contains more than 70 species grown worldwide $[1,2]$. In Pakistan it is grown in Gilgit-Baltistan, some parts of Khyber Pakhtunkhwa and Baluchistan provinces. A great varietal base if found in Gilgit-Baltistan which go more than 50. Market oriented preferences, climate change and poor management have squeezed rich varietal base and germ plasm diversity. More than $80 \%$ of populations differentially rely on income generated from its fresh, processed and value added products [3].

Grapes are famously known as 'The Queen of Fruits' [4]. Grapes are considered to contain antioxidants (polyphenols) $[5,6]$ which reduce the risk of different cancers including esophageal, lung, mouth, pharynx, endometrial, pancreatic, prostate and colon [7]. Similarly, resveratrol found in skin is considered beneficial for heart heath [8]. It also has proved effective for constipation, diabetes, indigestion, fatigue, kidney disorders, macular degeneration and the prevention of cataracts [9]. It is considered a rich sources of vitamin A, C, $\mathrm{B} 6$ and folate in addition to essential minerals like $\mathrm{K}, \mathrm{Ca}, \mathrm{Fe}$, $\mathrm{P}, \mathrm{Mg}$ and selenium [10,1]. The grape is composed of many macro nutrients and micro nutrients e.g. water $82 \%$, proteins $0.5-0.6 \%$ carbohydrates $12-18 \%$, and fats $0.3-$ $0.4 \%$. In addition to it, the grape contains significant amounts of potassium $0.1-0.2 \%$, vitamin C $0.01-0.02 \%$, and vitamin A $0.001-0.0015 \%$ [12]. Dried grapes are very fruitful in thirst on fevers, cough, inflammation of the mucous membranes of the nose and throat, jaundice, and in sub-acute cases of enlarged liver and spleen [13].

According to FAO statistics [18], there are ninety-four (94) countries in the world which produce grape. Among the top ten countries producing grapes are China, USA, Itley, Spain, France, Turkey, Argentina, India and Iran. Pakistan ranks 57 in the list of grape producing countries with an annual production of 66036 tonnes. Figure 1 shows the total production of grape in 2014 with highest figure against China with a total production of 12.63 million tonnes. 
Grape is considered one of the most remunerative summer fruit crops, native to warm, temperate zone between $34 \mathrm{oN}$ and $490 \mathrm{o}$ latitude. In Pakistan, grapes are grown over an area of 13,000 ha (FAO 42992 ha) with annual production of 49.0 thousand (FAO 0.066 million) tones. Differential climatic conditions are suitable for grape farming. Its crop requires long, warm, dry summers and cool winters for best development. Mountainous and sub-mountainous areas up to $2000 \mathrm{~m}$ altitude or more are suitable for its cultivation [19].

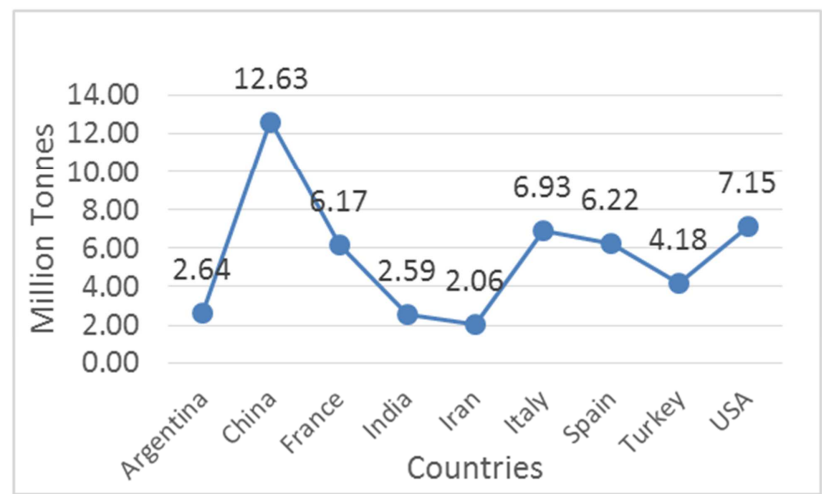

Figure 1. Countries with highest production of grape 2014.

With introduction of new grape varieties, grapes cultivation and farming is taking roots in new areas of Pakistan. New varieties introduced are even suitable for farming in Punjab province. This provides an opportunity for thousands of farmer communities to shift their agricultural products and produce towards new ways of earning cash through grape farming. According to Agribusiness of Pakistan [19], these provided grape varieties can generate earning around Rs. $1.6-2.0$ million (USD $0.019-0.02$ million) per [20].

According to Pakistan Agriculture Research Council [20] following ten seedless grape varieties are commonly grown in;

i. Thompson (Seedless)

ii. Perlette (Seedless)

iii. Red Globe (Seeded)

iv. Cardinal (Seeded)

v. Kings ruby (Seedless)

vi. Narc black (Seeded)

vii. Crimson (Seedless)

viii.Flame (Seedless)

ix. Sultana (Seedless)

x. Muscatil (Seeded)

[20]

Grapes are known to originate in Armenia, Russia or Georgia and in Turkey around 8000 years ago [14]. It was introduced to India and Pakistan as early as 1300 AD by Mughal assailant from Iran and Afghanistan [15, 16]. The Vitis vinifera has flaky bark, it has weak stem and branches have long shoots, the secondary shoots develop from the primary long shoots and tendril assist it to hold on to other structure. The height of plant is about $35 \mathrm{~m}$ and leaves are alternate and palmate in shape, lobed and broad. The length of leaves ranged from 5 to $20 \mathrm{~cm}$, the fruit is fleshy berry, known as a grape [17].

Study was carried out to characterize allometric growth which is important aspect of its cultivation, produce and productivity. There is a rich base of land races and cultivars in the area but undesired forces are forcing grapes to decline in its varietal richness. Study is unique in its nature and documents in the history of the area. More enriched and at greater scale studies are important to save and promote diversity among the germplasm variations in the area.

\section{Material and Method}

\subsection{Geography}

Research was carried out during March-October, 2016 in Hasis and adjacent villages in Puniyal region of district Ghizer, Gilgit-Baltistan, Pakistan. Puniyal region is well known for grape cultivation and production. Thousands of poor families rely on income generated from sale of fresh grapes and its byproducts like 'Kilaw'.

\subsection{Sample Frame}

The samples were randomly selected from Hasis Valley, Puniyal, district Ghizer.

\subsection{Sample Size}

Hundred plants $(\mathrm{N}=100)$ of Vitis vinifera were measured from ten different sites, ten from each site (population), hundred $(n=100)$ leaves, hundred seeds $(n=100)$ were collected from each site making a composite of $n=1000$ leaves and 1000 seeds.

\subsection{Parameters Studied}

The parameters studied include length of shoot (ft.), leaves length $(\mathrm{cm})$, leaves width $(\mathrm{cm})$, leaves area $\left(\mathrm{cm}^{2}\right)$, stem diameter $(\mathrm{cm})$ and seed weight $(\mathrm{mg} / \mathrm{g})$.

\subsection{Data Analysis}

Data gathered was processed using MS-Excel. Mean of each population was calculated like mean of population 1 (MP1) and so on mean population 10 (MP10). Mean of leaf length was indicated as $\mathrm{LL}(\mathrm{cm})$, width $(\mathrm{LW}-\mathrm{cm})$ and leaf area (LA-cm). similarly, mean stem/shoot length was expressed as SL $(\mathrm{cm})$ and diameter as SD $\left(\mathrm{cm}^{2}\right)$.

\section{Result and Discussion}

\subsection{Leaf}

Ten $(\mathrm{N}=10)$ different population studied revealed that mean leaf length is $10.9 \mathrm{~cm}$ (max. 13.4, $\min .9 .1 \mathrm{~cm}$ ) followed by mean leaf width $8.4 \mathrm{~cm}$ (max. 9.3, $\min .7 .1 \mathrm{~cm})$. total mean leaf area was $92.2 \mathrm{~cm}^{2}$ (max. 122.6, min. 70.9 $\mathrm{cm}^{2}$ ). See figure 2 for further details. 


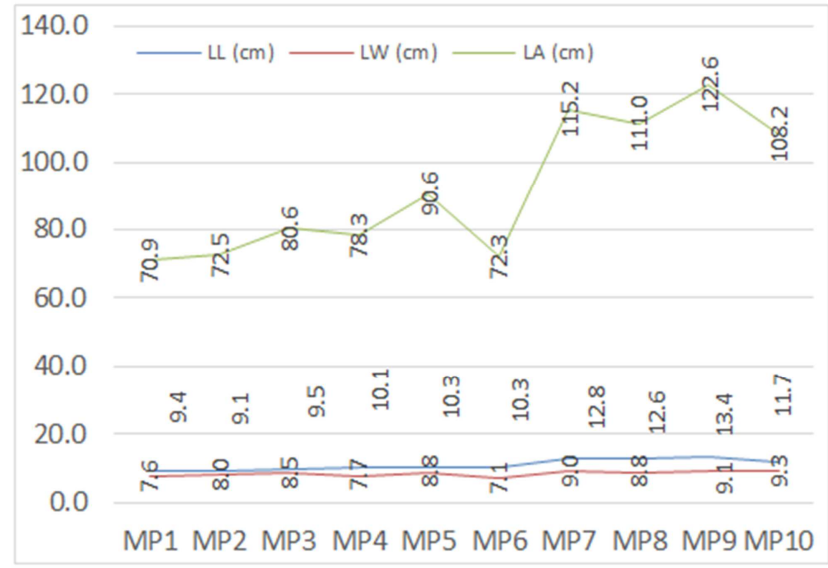

Figure 2. Leaf (leaf length, width and area (cm).

\subsection{Shoot/Stem}

Mean stem length recorded was 26.8 feet (max. 35, min. 16 feet) followed by mean stem width $8.44 \mathrm{~cm}$ (max. 12.8, $\min .3 .1 \mathrm{~cm}$ ). see figure 3 .

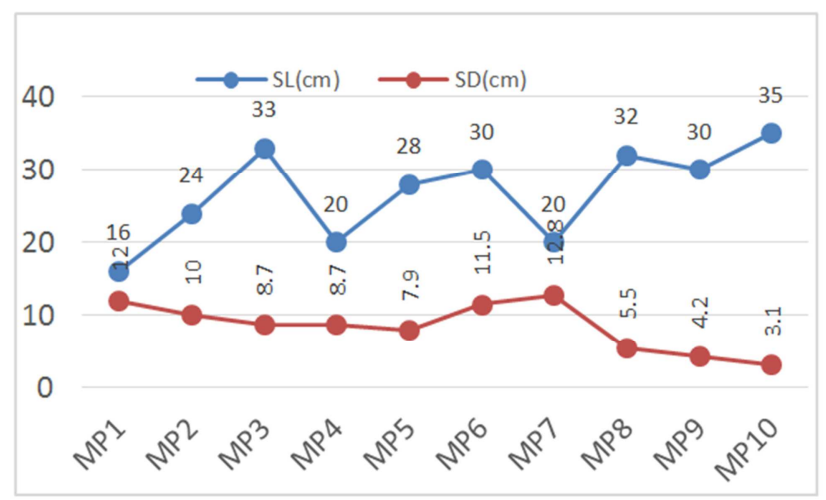

Figure 3. Mean stem length and width (cm).

\subsection{Seed}

One thousand seeds were measured and mean seed weight recorded was $0.043 \mathrm{mg}$ (max. 0.047, min. 0.039). similarly mean weight of hundred $(n=100)$ seeds recorded was $4.29 \mathrm{~g}$. see figure 4 .

\subsection{Discussion}

Research area is experiencing a rapid climate change which has a profound impact on the grape cultivation and production. Most of the poor families depend on the grape production and its sale annually. Grapes are not only a source of income generation but make most of food composition through its fresh and processing for making of byproducts contribute towards food security as well. Ruthless climate change, insufficient management practices and market dictations can create some financial, livelihood and food security issues in the next $10-20$ years. Therefore, it is recommended that further investigation is required to document on scientific basis including their land races which have never been explored from the area. Area holds rich germ plasm but continued ignorance from government departments and other several non-governmental organization besides farmers themselves can lead to depletion of precious germ plasm as well.

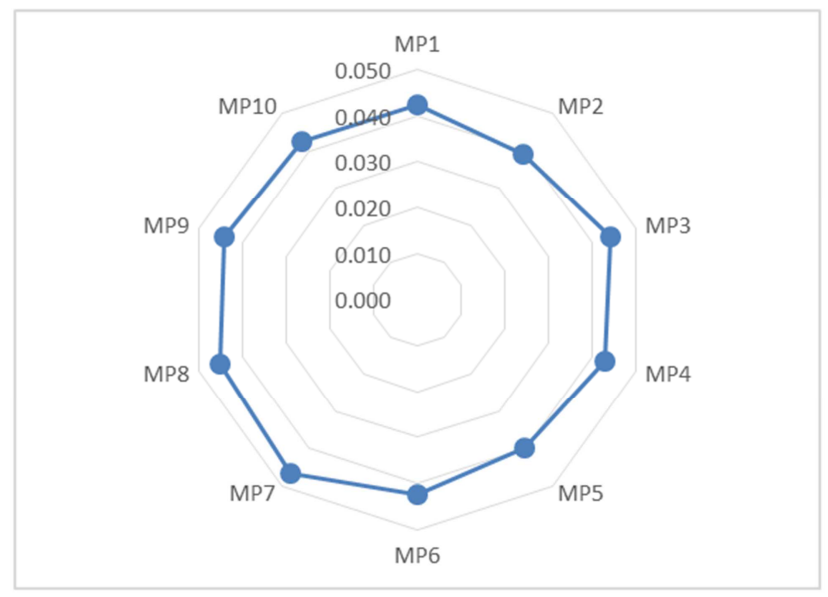

Figure 4. Seed weight (mg) mean of means.

\section{Conclusion}

Keeping its importance from scientific, socio-economic and livelihood perspectives, it is important to educate and train poor farmers to improve their management practices which are a great hindrance toward getting good production. Moreover, government needs to introduce new seedless varieties besides promoting research and conservation of land races in the area.

\section{Acknowledgement}

I would like to express my appreciations to my teacher doctoral scholar Tika Khan, faculty department of Biological Sciences, Karakorum International University, GilgitBaltistan for his invaluable facilitation and guide during this research and research paper development.

\section{References}

[1] Alleweldt, G., \& Possingham, J. V. (1988). Progress in grapevine breeding. Theoretical and Applied Genetics, 75(5), 669-673.

[2] Lodhi, M. A., Ye, G. N., Weeden, N. F., \& Reisch, B. I. (1994). A simple and efficient method for DNA extraction from grapevine cultivars and Vitis species. Plant Molecular Biology Reporter, 12(1), 6-13.

[3] Finetto, G. A. (2007, October). The Temperate Fruit Tree Industry in Afghanistan: Economic and Food Security Importance as a Sustainable Alternative Livelihood. In VIII International Symposium on Temperate Zone Fruits in the Tropics and Subtropics 872 (pp. 389-398).

[4] Choudhary, T. 2017. 20 Benefits of Grapes (Angoor) For Skin, Hair, And Health. Retrieved from http://www.stylecraze.com/articles/top-10-health-benefits-ofgrapes/\#gref on June 6, 2017. 
[5] Doshi, P., Adsule, P., \& Banerjee, K. (2006). Phenolic composition and antioxidant activity in grapevine parts and berries (Vitis vinifera L.) cv. Kishmish Chornyi (Sharad Seedless) during maturation. International journal of food science \& technology, 41(s1), 1-9.

[6] Negro, C., Tommasi, L., \& Miceli, A. (2003). Phenolic compounds and antioxidant activity from red grape marc extracts. Bioresource Technology, 87(1), 41-44.

[7] Jang, M., Cai, L., Udeani, G. O., Slowing, K. V., Thomas, C. F., Beecher, C. W., \& Moon, R. C. (1997). Cancer chemopreventive activity of resveratrol, a natural product derived from grapes. Science, 275(5297), 218-220.

[8] Bertelli, A. A., \& Das, D. K. (2009). Grapes, wines, resveratrol, and heart health. Journal of cardiovascular pharmacology, 54(6), 468-476.

[9] Ware, M. 2016. Grapes: Health Benefits, Facts, Research. In: NEWSLETTER. Retrieved from $\mathrm{http} / / /$ www.medicalnewstoday.com/articles/271156.php on June 6, 2017.

[10] Kim, S. H., \& Keen, C. L. (2002). Vitamin and mineral supplement use among children attending elementary schools in Korea: a survey of eating habits and dietary consequences. Nutrition research, 22(4), 433-448.

[11] Hunt, C. D., Johnson, P. E., Herbel, J., \& Mullen, L. K. (1992). Effects of dietary zinc depletion on seminal volume and zinc loss, serum testosterone concentrations, and sperm morphology in young men. The American journal of clinical nutrition, 56(1), 148-157.

[12] Yadav, M., Jain, S., Bhardwaj, A., Nagpal, R., Puniya, M., Tomar, R., \& Yadav, H. (2009). Biological and medicinal properties of grapes and their bioactive constituents: an update. Journal of medicinal food, 12(3), 473-484.
[13] Onyishi, I. V., Chime, S. A., \& Okeke, C. (2013). Evaluation of the antioxidant properties of Vitis vinifera juice extract in rifampicin dispersions. African Journal of Pharmacy and Pharmacology, 7(24), 1619-1624.

[14] This, P., Lacombe, T., \& Thomas, M. R. (2006). Historical origins and genetic diversity of wine grapes. TRENDS in Genetics, 22(9), 511-519.

[15] Grnacarevic, M. (1969). Drying and processing grapes in Afghanistan. American Journal of Enology and Viticulture, 20(3), 198-202.

[16] Krithik, V., Naik, R., Pragal, Y. (2015). Functional properties of grape (Vitis vinifera) seed extract and possible extraction techniques -agricultural research communication center arcs journals DOL: 10-18805/ag. v36i4.

[17] Urbi. Z, Hossain M. S, Rehman K. M. H (2014) grape: a medicinal fruit species in the holy Quran and its ethno medicinal importance- world applied sciences journal 30(3).

[18] FAO. 2017. Crops. FAOSTAT. Food and Agriculture Organization of the United Nations. Available at http://www.fao.org/faostat/en/\#data/QC

[19] AIB. 2017. Pakistan: high value early maturing grapes varieties for monsoon rain fall region of Punjab. Agriculture Information Bank. Available at http://agrinfobank.blogspot.com/2012/12/pakistan-high-valueearly-maturing.html.

[20] PARC. 2017. Varieties of Grapes in Pakistan. Pakistan Agricultural Research Council. Available at http://www.agribusiness.com.pk/varieties-of-grapes-inpakistan. 